\title{
Myeloid peroxisome proliferator-activated receptor $\alpha$ deficiency accelerates liver regeneration via IL-6/STAT3 pathway after 2/3 partial hepatectomy in mice
}

\author{
Guomin Xie ${ }^{1,2}$, Yanting Song ${ }^{1,2}, \mathrm{Na} \mathrm{Li}^{3}$, Zhenzhen Zhang ${ }^{4}$, Xia Wang ${ }^{1,2}$, Ye Liu ${ }^{1,2}$, Shiyu Jiao ${ }^{1,2}$, \\ Ming Wei ${ }^{1,2}$, Baoqi Yu ${ }^{1,2}$, Yan Wang ${ }^{4}$, Hua Wang ${ }^{5}$, Aijuan $\mathbf{Q u}^{1,2}$ \\ ${ }^{1}$ Department of Physiology and Pathophysiology, School of Basic Medical Sciences, Capital Medical University, Beijing, China; ${ }^{2}$ Key Laboratory of \\ Remodeling-Related Cardiovascular Diseases, Ministry of Education, Beijing, China; ${ }^{3}$ Department of Endocrinology, Beijing Chaoyang Hospital \\ Affiliated to Capital Medical University, Beijing, China; ${ }^{4}$ Department of Infectious Diseases, Peking University First Hospital, Beijing, China; \\ ${ }^{5}$ Department of Oncology, the First Affiliated Hospital of Anhui Medical University, Hefei, China \\ Contributions: (I) Conception and design: G Xie, A Qu, H Wang, Y Wang; (II) Administrative support: A Qu, H Wang, Y Wang, X Wang, B Yu; (III) \\ Provision of study materials or patients: A Qu, H Wang, Y Wang; (IV) Collection and assembly of data: G Xie, Y Song, N Li, Z Zhang, X Wang, Y \\ Liu, S Jiao, M Wei; (V) Data analysis and interpretation: G Xie, Y Song, B Yu, Y Wang, H Wang, A Qu; (VI) Manuscript writing: All authors; (VII) \\ Final approval of manuscript: All authors. \\ Correspondence to: Yan Wang, MD. Department of Infectious Diseases, Peking University First Hospital, No. 8 Xishiku Street, Beijing 100034, China. \\ Email: wangyanwang@bjmu.edu.cn; Hua Wang, MD, PhD. Department of Oncology, the First Affiliated Hospital of Anhui Medical University, 218 \\ Jixi Rd., Hefei 230032, China. Email: wanghua@ahmu.edu.cn; Aijuan Qu, MD, PhD. Department of Physiology and Pathophysiology, School of \\ Basic Medical Sciences, Capital Medical University, 10 You'anmen Outer West 1st Street, Beijing 100069, China. Email: aijuanqu@ccmu.edu.cn.
}

Background: Liver regeneration is a fundamental process for sustained body homeostasis and liver function recovery after injury. Emerging evidence demonstrates that myeloid cells play a critical role in liver regeneration by secreting cytokines and growth factors. Peroxisome proliferator-activated receptor $\alpha(\operatorname{PPAR} \alpha)$, the target of clinical lipid-lowering fibrate drugs, regulates cell metabolism, proliferation, and survival. However, the role of myeloid $\mathrm{PPAR} \alpha$ in partial hepatectomy (PHx)-induced liver regeneration remains unknown.

Methods: Myeloid-specific PPARa-deficient $\left(P p a r a^{\mathrm{Mye}-/-}\right)$ mice and the littermate controls $\left(P_{\left.p a r a^{\mathrm{fl} / \mathrm{fl}}\right)}\right)$ were subjected to sham or 2/3 $\mathrm{PHx}$ to induce liver regeneration. Hepatocyte proliferation and mitosis were assessed by immunohistochemical (IHC) staining for 5-bromo-2'-deoxyuridine (BrdU) and Ki67 as well as hematoxylin and eosin (H\&E) staining. Macrophage and neutrophil infiltration into livers were reflected by IHC staining for galectin-3 and myeloperoxidase (MPO) as well as flow cytometry analysis. Macrophage migration ability was evaluated by transwell assay. The mRNA levels for cell cycle or inflammation-related genes were measured by quantitative real-time RT-PCR (qPCR). The protein levels of cell proliferation related protein and phosphorylated signal transducer and activator of transcription 3 (STAT3) were detected by Western blotting.

Results: Ppara ${ }^{\mathrm{Mye}-/-}$ mice showed enhanced hepatocyte proliferation and mitosis at $32 \mathrm{~h}$ after $\mathrm{PHx}$ compared with $P_{p a r a}^{\mathrm{A} / \mathrm{l}}$ mice, which was consistent with increased proliferating cell nuclear antigen (Pcna) mRNA and cyclinD1 (CYCD1) protein levels in Ppara ${ }^{\text {Mye-/- }}$ mice at $32 \mathrm{~h}$ after PHx, indicating an accelerated liver regeneration in $\mathrm{Ppara}^{\mathrm{Mye-/}}$ mice. IHC staining showed that macrophages and neutrophils were increased in Para $^{\text {Mye-- }}$ liver at $32 \mathrm{~h}$ after PHx. Livers of ppara $^{\text {Mye-/- }}$ mice also showed an enhanced infiltration of M1 macrophages at $32 \mathrm{~h}$ after PHx. In vitro, Ppara-deficient bone marrow-derived macrophages (BMDMs) exhibited markedly enhanced migratory capacity and upregulated M1 genes Il6 and Tnfa but downregulated M2 gene Arg1 expressions. Furthermore, the phosphorylation of STAT3, a key transcript factor mediating IL6-promoted hepatocyte survival and proliferation, was reinforced in the liver of Ppara ${ }^{\text {Mye-/- }}$ mice after PHx. Conclusions: This study provides evidence that myeloid PPAR $\alpha$ deficiency accelerates PHx-induced liver regeneration via macrophage polarization and consequent IL-6/STAT3 activation, thus providing a potential target for manipulating liver regeneration. 


\begin{abstract}
Keywords: Liver regeneration; peroxisome proliferator-activated receptor $\alpha$ (PPAR $\alpha)$; myeloid cell; signal
\end{abstract} transducer and activator of transcription 3 (STAT3); interleukin 6 (IL-6)

Submitted Sep 01, 2020. Accepted for publication Jan 19, 2021.

doi: $10.21037 / \mathrm{hbsn}-20-688$

View this article at: http://dx.doi.org/10.21037/hbsn-20-688

\section{Introduction}

Liver is the only organ that maintains a remarkable capacity to regenerate through hepatocellular hypertrophy and hyperplasia, which is described in experimental models, such as two-thirds partial hepatectomy $(\mathrm{PHx})$ in rodents (1). The regenerative capability protects the organism from parenchyma loss, which may be caused by hepatotoxins, chronic infection, $\mathrm{PHx}$, and liver transplantation. Impaired regeneration exacerbates liver dysfunction during the above processes. Understanding the hepatic regenerative process is of great clinical significance as the effectiveness of many treatments for chronic liver diseases, such as donor liver transplantation and tumor resections, depends on efficient liver regeneration. Accordingly, it is necessary to explore new therapeutic targets for liver regeneration.

Liver regeneration is a tightly controlled and compensatory process, in which multiple cell types and signaling molecules are involved. For instance, early after $\mathrm{PHx}$, increased secretion and utility of growth factors [hepatocyte growth factor (HGF), epidermal growth factor (EGF)], hormones (norepinephrine, insulin, serotonin), and cytokines [interleukin 6 (IL-6), tumor necrosis factor $\alpha(\mathrm{TNF}-\alpha)$ ] are initiated and consequently prime the activation of transcription factors [signal transducer and activator of transcription (STAT) 3; nuclear factor $\mathrm{\kappa B}$ $(\mathrm{NF}-\kappa \mathrm{B}) ; \beta$-catenin]. These early events guide the changes in transcriptome and the following cell cycle progression of quiescent hepatocytes. Subsequently, the parenchymal and nonparenchymal cells proliferate until the liver mass is restored (2-5). However, the source of the cytokines and growth factors have not been fully explored.

Abundance experimental evidence points that the innate and adaptive immune cells are necessary for normal liver regeneration after $\mathrm{PHx}$ (6-8). After acute liver injury, damaged hepatocyte releases danger-associated molecular patterns (DAMPs) activate Kupffer cells and hepatic stellate cells, resulting in the release of chemokines, such as CCL2 and IL-8 (CXCL8), that recruit myeloid cells into local areas of inflammation (9). Gut-derived factors, such as lipopolysaccharide (LPS), activate hepatic Kupffer cells and promote them to produce TNF- $\alpha$ and IL- 6 . IL- 6 binds to its receptor on hepatocytes, triggers activation of the Janus kinase (JAK)-STAT3 pathway, and ultimately promotes hepatocyte survival and proliferation $(2,4,6,10)$. Hitherto the transcription factors regulating myeloid cell function during PHx are not completely understood.

Nuclear receptor peroxisome proliferator-activated receptor $\alpha(P P A R \alpha)$ is the target of widely-used hypolipidemic fibrate drugs mainly via control of fatty acid metabolism (11). Short-term PPAR $\alpha$ activation by its synthetic agonist fibrates and $\mathrm{Wy}-14643$ induces hepatomegaly, and long-term activation causes hepatocarcinogenesis in a PPAR $\alpha$-dependent manner in rodents (12-15). Whole-body knockout of PPAR $\alpha$ impairs PHx-induced liver regeneration $(16,17)$, whereas hepatocyte-specific PPAR $\alpha$ deficiency has a less extent of impairment in $\mathrm{PHx}$-induced liver regeneration than the PPAR $\alpha$ whole-body knockout (18), indicating that nonparenchymal PPAR $\alpha$ may also play a certain role in $\mathrm{PHx}$ induced liver regeneration. Recent studies suggested that PPAR $\alpha$ activation is critical for the anti-inflammatory effects of myeloid cells $(19,20)$. However, the role of myeloid PPAR $\alpha$ in PHx-induced liver regeneration remains unknown.

In this study, the role of myeloid PPAR $\alpha$ in PHx-induced liver regeneration was explored by genetic manipulation of PPAR $\alpha$ in myeloid cells. Myeloid PPAR $\alpha$-deficient $\left(\right.$ Ppara $\left.^{\mathrm{Mye}-/-}\right)$ mice exhibited accelerated liver regeneration after PHx. Mechanistically, PPAR $\alpha$ deficiency increased IL-6 expression in myeloid cells via promoting M1 polarization and consequently activated STAT3 in the liver, thus providing a potential target for manipulating liver regenerative disease. We present the following article in accordance with the ARRIVE reporting checklist (available at https://hbsn.amegroups.com/article/view/10.21037/ hbsn-20-688/rc). 


\section{Methods}

\section{Animal experiments}

C57BL/6J wild-type mice were purchased from Charlies River Company (Beijing, China). Ppara ${ }^{\mathrm{f} / \mathrm{fl}}$ and myeloidspecific Ppara-deficient (Ppara $\left.{ }^{\mathrm{f} / \mathrm{fl} / \mathrm{Lys} \mathrm{M}-\mathrm{Cre}}, \mathrm{Ppara}^{\mathrm{Mye}-/-}\right)$ mice were generated as described previously (20). All mice were housed and bred in the animal facilities at Capital Medical University according to Chinese guidelines. All animals were maintained on a 12 -h light/12-h dark cycle and free access to food and water. Animal experiments were performed under a project license (AEEI-2018-127) granted by ethics board of Capital Medical University.

Eight- to 10-week-old male $P_{p a r a} a^{\mathrm{f} / \mathrm{fl}}$ and $P_{p a r a}{ }^{\mathrm{Mye}-/-}$ mice were used in this study. Two-thirds PHx-induced liver regeneration models were performed as previously described $(21,22)$. Mice were injected with 5-bromo-2'deoxyuridine (BrdU, $50 \mathrm{mg} / \mathrm{kg}$ body weight) $2 \mathrm{~h}$ before sacrificing at the indicated time points. Liver tissues were fixed in formalin, embedded in paraffin, or frozen in optimal cutting temperature compound (OCT) for cryosection, whereas the remaining liver tissue was snap-frozen for further analysis.

\section{Hematoxylin and eosin $(H \& E)$ staining and immunobistochemistry staining}

Paraffin-embedded liver tissues were cut into sections (4- $\mu \mathrm{m}$ thick) for $\mathrm{H} \& \mathrm{E}$ and immunohistochemistry staining. H\&E staining was performed following standard methods. Immunohistochemistry analysis was performed using antibodies against galectin-3 (Santa Cruz Biotechnology, California, USA), myeloperoxidase (MPO) (Abcam, Cambridge, UK) and Ki67 [Cell Signaling Technology (CST), Boston, USA] following standard instructions and antibodies against BrdU (BD Bioscience, San Jose, CA, USA), as previously described (23).

\section{Liver macrophage isolation}

Mouse liver macrophages were separated by gradient centrifugation as previous described (24). Briefly, mouse liver was perfused and digested with collagenase solution. Liver was further digested with Dulbecco's Modified Eagle's Medium (DMEM, Corning, New York, USA) containing $1 \%$ collagenase IV in a $37{ }^{\circ} \mathrm{C}$ water bath for $30 \mathrm{~min}$ in vitro. After filtering the liver cell suspension, cells were centrifuged twice at $50 \mathrm{~g}$ for $2 \mathrm{~min}$ to remove hepatocytes.
Hepatic nonparenchymal cells were further centrifuged at $400 \mathrm{~g}$ for $10 \mathrm{~min}$. Cell pellets were resuspended with Percoll gradient $(25 \%+50 \%)$ solution and centrifuged at $1,600 \mathrm{~g}$ for $17 \mathrm{~min}$ without a break. macrophage layers (between 25\% and 50\% Percoll gradient) were collected, washed with PBS, and resuspended in DMEM containing $10 \%$ fetal bovine serum (FBS) and $100 \mathrm{U} / \mathrm{mL}$ of penicillin/ streptomycin. Cells were cultured in a six-well plate at $37^{\circ} \mathrm{C}$. After $4 \mathrm{~h}$, nonadherent cells were removed by aspiration and macrophages were washed with PBS 3 times.

\section{Bone marrow-derived macrophages (BMDMs) isolation and treatment}

Bone marrow-derived cells were isolated from the femurs and tibias of adult $P_{p a r a} a^{\mathrm{t} / \mathrm{ll}}$ and $\mathrm{Ppara}^{\mathrm{Mye}-/-}$ mice as previously described (25). Cells were planted in DMEM complete medium (10\% FBS and $100 \mathrm{U} / \mathrm{mL}$ of penicillin/ streptomycin) and stimulated with murine macrophage colony stimulating factor $(50 \mathrm{ng} / \mathrm{mL})$ for 3 days to allow the differentiation into macrophages. For cell experiment, the BMDMs were stimulated with vehicle and LPS $(100 \mathrm{ng} / \mathrm{mL})$ for $3 \mathrm{~h}$ to simulate inflammation response.

\section{Flow cytometry}

Liver non-parenchymal cells were isolated and single-cell suspensions were treated with Fc block, washed, and stained with CD45 percpCy5.5 (557235, BD, USA), CD11b FITC (557396, BD, USA), F4/80 BV421 (565411, BD, USA), Ly6G APC (560599, BD, USA), CD206 PE (141706, BD, USA), and their homologous isotype-matched negative controls (BD, Franklin Lakes, NJ, USA). In the basis of a live gate, events were acquired on a Fortessa flow cytometer (BD, USA) and analyzed by FlowJo V10 software (BD, USA).

\section{Transwell migration assay}

BMDMs were seeded at a density of $2 \times 10^{6}$ cells $/ \mathrm{mL}$ in a 5 - $\mu \mathrm{m}$ pore-size transwell chamber (Corning, New York, USA) with DMEM containing $1 \%$ FBS and $100 \mathrm{U} / \mathrm{mL}$ of penicillin/streptomycin. DMEM containing 10\% FBS were added in the bottom of each well as a chemoattractant. After incubation at $37^{\circ} \mathrm{C}$ for $24 \mathrm{~h}$, chambers were removed and washed by PBS, fixed with $4 \%$ paraformaldehyde for $20 \mathrm{~min}$, stained with $0.25 \%$ crystal violet (DZ0059, Leagene, Beijing, China) for $20 \mathrm{~min}$ and cells in the upper chamber were depleted. The average value of migrated cells 
was counted in five fields per membrane to determine the migration ability.

\section{RNA extraction and real-time quantitative PCR}

Total RNA was extracted from the liver tissues, BMDMs, or liver macrophages of $P_{p a r a} a^{\mathrm{A} / \mathrm{t}}$ and $\mathrm{Ppara}^{\mathrm{Mye}-/-}$ mice using TRIzol reagent (Life Technologies, Carlsbad, CA, USA). One $\mu \mathrm{g}$ of total RNA was reverse-transcribed into cDNA with GoScript Reverse Transcriptase (Promega, Madison, USA) and subjected to quantitative real-time RT-PCR (qPCR) analysis with SYBR Green premix (TaKaRa, Nojihigashi, Kusatsu, Shiga, Japan) on CFX Connect RealTime System (Bio-Rad, Hercules, CA, USA). Relative expression of target genes was calculated by $2^{-\Delta \Delta \mathrm{Ct}}$ method and normalized to that of the housekeeping gene Actb mRNA. The primers are listed in Table S1.

\section{Western blot}

Whole-cell lysate was extracted using tissue protein extraction reagent (Thermo Scientific, Waltham, MA, USA). The protein concentration was measured using the bicinchoninic acid protein assay kit (Thermo Scientific). Specific primary antibodies used were as follows: antibodies against pSTAT3 (CST, Boston, USA), STAT3 $\alpha$ (CST, Boston, USA), pSTAT1 (CST, Boston, USA), STAT1 (CST, Boston, USA), ACTB (Proteintech, Chicago, USA). The dilutions were 1:1,000 in 5\% bovine serum albumin. After incubating with horseradish peroxidase-conjugated secondary antibody (MilliporeSigma, Darmstadt, Germany), the immunocomplexes were visualized with FluorChem-R (ProteinSimple, San Jose, CA, USA). Total protein levels were normalized to ACTB.

\section{Statistical analysis}

The mean \pm standard deviation (SD) was calculated and plotted using GraphPad Prism 7 software (GraphPad Software, San Diego, California, USA). Comparisons between two groups were performed using two-tailed unpaired Student's $t$-test. Differences between multiple groups with one variable were determined using oneway analysis of variance (one-way ANOVA) followed by Bonferroni's post-hoc test. To compare multiple groups with more than one variable, two-way ANOVA followed by Bonferroni's post-hoc test was used. $\mathrm{P}<0.05$ was considered statistically significant.

\section{Results}

\section{Deficiency of myeloid PPARa accelerates $\mathrm{PH}$-induced liver regeneration}

To explore the role of myeloid PPAR $\alpha$ in PHx-induced hepatocyte proliferation, $\mathrm{Ppara}^{\mathrm{f} / \mathrm{fl}}$ mice were crossed with transgenic mice expressing Cre recombinase under control of lysozyme 2 (LysMCre) promoters to generate myeloidspecific Ppara knockout ( Ppara $^{\text {Mye-/-_}}$ ) mice as previous described (20). PCR analyses demonstrated Cre allele and Ppara homogenous alleles in $P_{p a r a}{ }^{\text {Mye-/- }}$ genomic DNA (Figure $1 A, 1 B$ ). qPCR analysis showed that Ppara mRNA level was specifically decreased in BMDMs from Ppara $^{\text {Mye-/- }}$ mice but not from Ppara ${ }^{\mathrm{f} / \mathrm{fl}}$ mice (Figure 1C), indicating a successful construction of myeloid-specific Ppara-deficient mice.

The $\mathrm{Ppara}^{\mathrm{A} / \mathrm{l}}$ and $\mathrm{Ppara}^{\mathrm{Mye}-/-}$ mice were subjected to $2 / 3$ PHx operation. H\&E staining showed a raised number of mitotic cells in Ppara ${ }^{\text {Mye-/- }}$ liver at $32 \mathrm{~h}$ (Figure $2 A$ ). Immunohistochemical staining demonstrated an increase of $\mathrm{BrdU}^{+}$(Figure 2B,2C) and Ki67 (Figure 2D,2E) hepatocytes at $32 \mathrm{~h}$ but dropdown at $40 \mathrm{~h}$ after PHx in $\mathrm{Ppara}^{\text {Mye-/- }}$ mice compared with $P$ para ${ }^{\mathrm{f} / \mathrm{fl}}$ mice. Consistently, the liver-tobody weight of $P$ para ${ }^{\text {Mye-/- }}$ mice was increased at $32 \mathrm{~h}$ than that of $P_{p a r a}{ }^{\mathrm{f} / f \mathrm{l}}$ mice (Figure $2 F$ ). Taken together, these results indicate an accelerated liver regeneration in myeloid PPAR $\alpha$-deficient mice after PHx.

\section{PPAR $\alpha$ disruption in myeloid cells promotes cell cycle progression after $\mathrm{PHx}$}

To further confirm whether myeloid PPAR $\alpha$ deficiency accelerates $\mathrm{PHx}$-induced liver regeneration, the cell cycle-related genes, such as Pcna, Ccnd1, Ccna2 and Ccne1 were measured by qPCR analysis. As shown in Figure 3, Ccnd1 and Pcna mRNA were increased at $32 \mathrm{~h}$ after PHx (Figure 3A,3B) in Ppara ${ }^{\mathrm{Mye}-/}$ mouse liver compared to Ppara ${ }^{\mathrm{A} / \mathrm{H}}$ mice, indicating an advanced G1-S progression after myeloid PPARa deficiency. However, Ccna2 and Ccne1 expression was comparable between these two groups (Figure 3C,3D). Western blot analyses also confirmed an enhanced CYCD1 expression at $32 \mathrm{~h}$ after $\mathrm{PHx}$ in $P_{p a r a}{ }^{\text {Mye-/- }}$ mice compared to Ppara ${ }^{\mathrm{A} / \mathrm{fl}}$ mice (Figure $3 E, 3 F$ ). However, the PCNA protein expression was comparable in $P_{p a r a}{ }^{\mathrm{fl} / \mathrm{fl}}$ and $P_{\text {para }}{ }^{\mathrm{Mye}-/-}$ mice at $32 \mathrm{~h}$ after $\mathrm{PHx}$ (Figure $3 E, 3 G$ ). It is reported that mitogenic growth factors HGF and EGF involved in regulating liver regeneration (26). Therefore, the expression $H g f$ and $E g f$ 

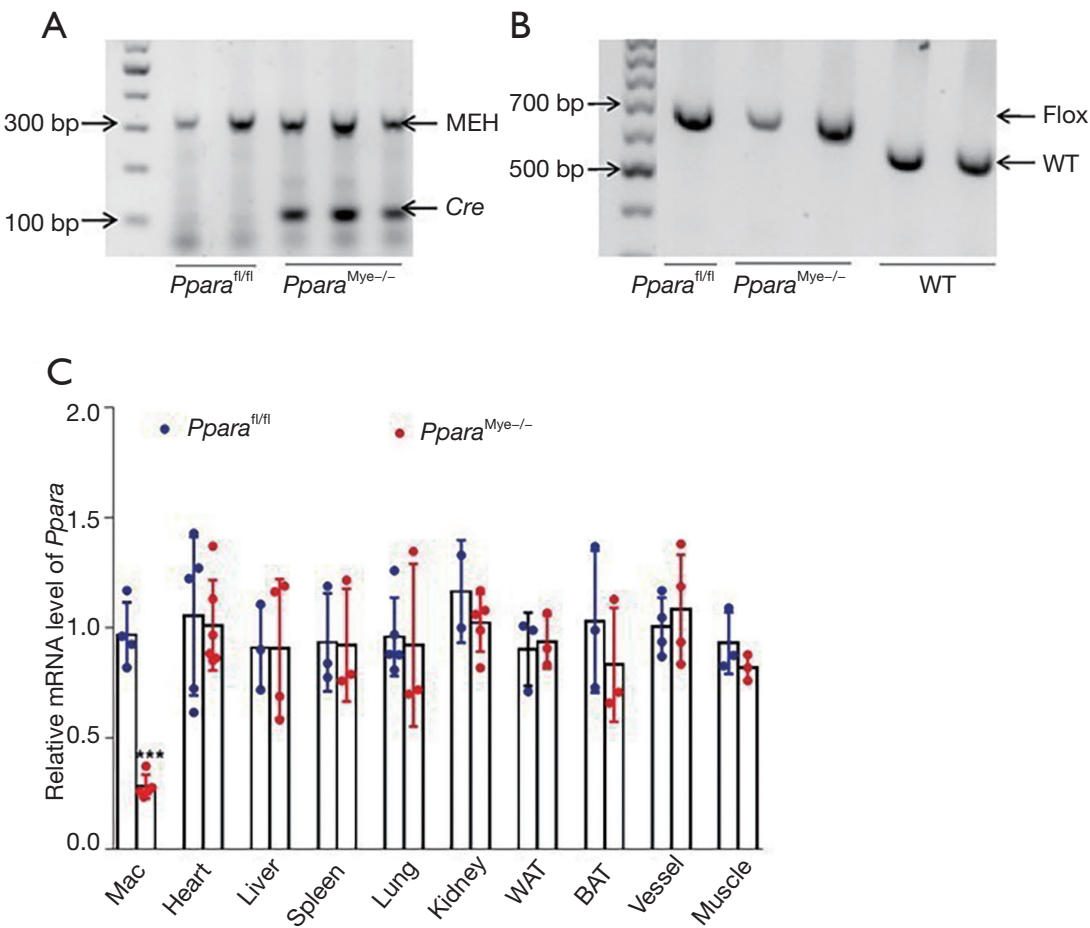

Figure 1 Identification of myeloid PPAR $\alpha$-deficient mice. (A,B) PCR analyses for Cre and Ppara allele in genomic DNA from Ppara ${ }^{\mathrm{A} / \mathrm{fl}}$ and Ppara $^{\mathrm{Mye}-/-}$ mice. (C) qPCR analysis for Ppara mRNA levels in macrophages or tissues from Ppara ${ }^{\mathrm{A} / \mathrm{fl}}$ and $P_{p a r a^{\mathrm{Mye}-/-}}$ mice (n=3-5). Data are expressed as means $\pm \mathrm{SD}, \mathrm{n}=3-5$. ${ }^{* * *}, \mathrm{P}<0.001$. MEH, musculus epoxide hydrolase 1 ; WT, wild type; Mac, macrophage; WAT, white adipose tissue; BAT, brown adipose tissue; qPCR, quantitative real-time RT-PCR.

was measured, no difference was found between $P$ para ${ }^{\mathrm{A} / \mathrm{f}}$ and $P_{\text {para }}{ }^{\text {Mye-/ }}$ mice at $32 \mathrm{~h}$ after PHx (data not shown). These results indicating that $H g f$ and $E g f$ may not be the main genes regulated by myeloid PPAR $\alpha$ in liver regeneration. These results confirm an accelerated G1-S progression in $\mathrm{Ppara}^{\mathrm{Mye}-/}$ mice after PHx.

\section{Myeloid PPARa deficiency promotes M1 phenotype macrophage infiltration to the liver at $32 \mathrm{~b}$ after $\mathrm{PH} x$}

It is well established that inflammatory cells infiltrate into the liver after acute $\mathrm{PHx}$ operation and promotes liver regeneration (7). To investigate the influence of myeloid PPAR $\alpha$ in inflammatory cells infiltration to liver, immunohistochemical staining for MPO (Figure 4A,4B) and galectin-3 (Figure $4 C, 4 D$ ) was performed. There was a marked increase of neutrophil and macrophage infiltration to the liver at $32 \mathrm{~h}$ after $\mathrm{PHx}$ in $\mathrm{Ppara}^{\mathrm{Mye}-\mathrm{I}}$ mice compared with $P$ para ${ }^{\mathrm{A} / \mathrm{f}}$ mice. To deeply understanding the relationship between myeloid PPAR $\alpha$ and liver regeneration, the flow cytometry assay was performed. PPAR $\alpha$ deficiency in myeloid cells dramatically increased the infiltration of

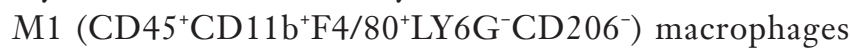
at $32 \mathrm{~h}$ after PHx (Figure $4 E, 4 F$ ). In vitro, the Pparadeficient BMDMs exhibited markedly enhanced migratory capacity as reflected by modified Boyden chamber assay (Figure 4G,4H). Taken together, myeloid PPAR $\alpha$ deficiency promotes liver macrophage infiltration by promoting macrophage migration at $32 \mathrm{~h}$ after $\mathrm{PHx}$.

\section{Myeloid PPARa deficiency enhances BMDMs polarization to M1 phenotype}

IL-6 pathways are essential for most of the immediate early gene expression to lead quiescent hepatocytes into a proliferative state after PHx operation (27-29) and M1 macrophages secreting IL- 6 and TNF- $\alpha$ (30). To further understating the role of myeloid PPAR $\alpha$ in macrophage polarization and liver regeneration, the mRNA level of Il6 and Tnfa in liver tissues was measured. qPCR analysis showed enhanced expression of Il6 and Tnfa at $32 \mathrm{~h}$ in livers of $\mathrm{Ppara}^{\mathrm{Mye}-/-}$ mice after PHx compared with $\mathrm{Ppara}^{\mathrm{A} / \mathrm{fl}}$ 


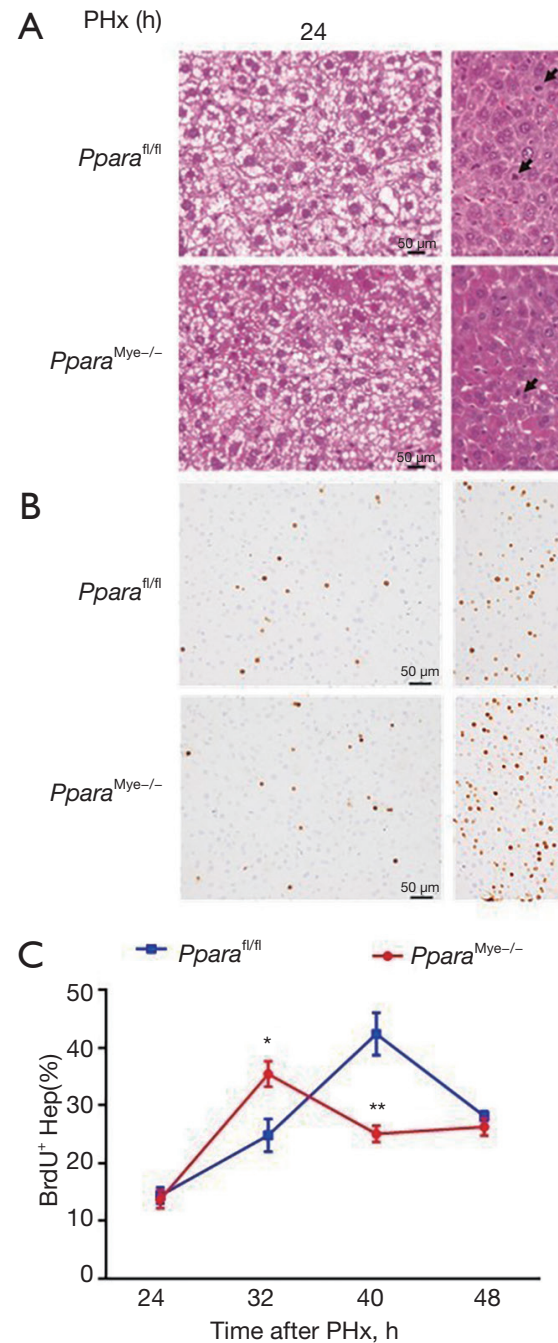

32
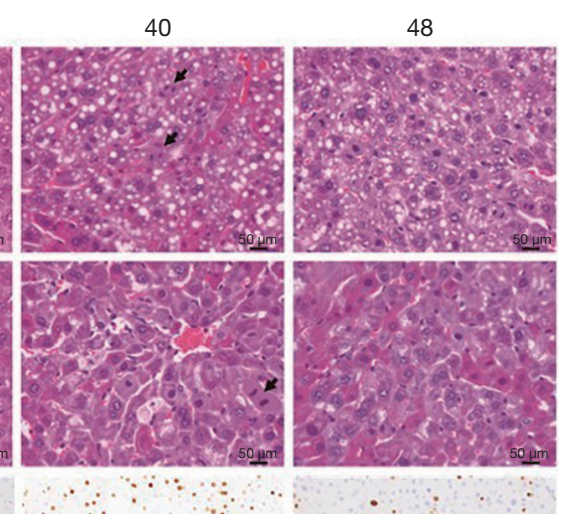
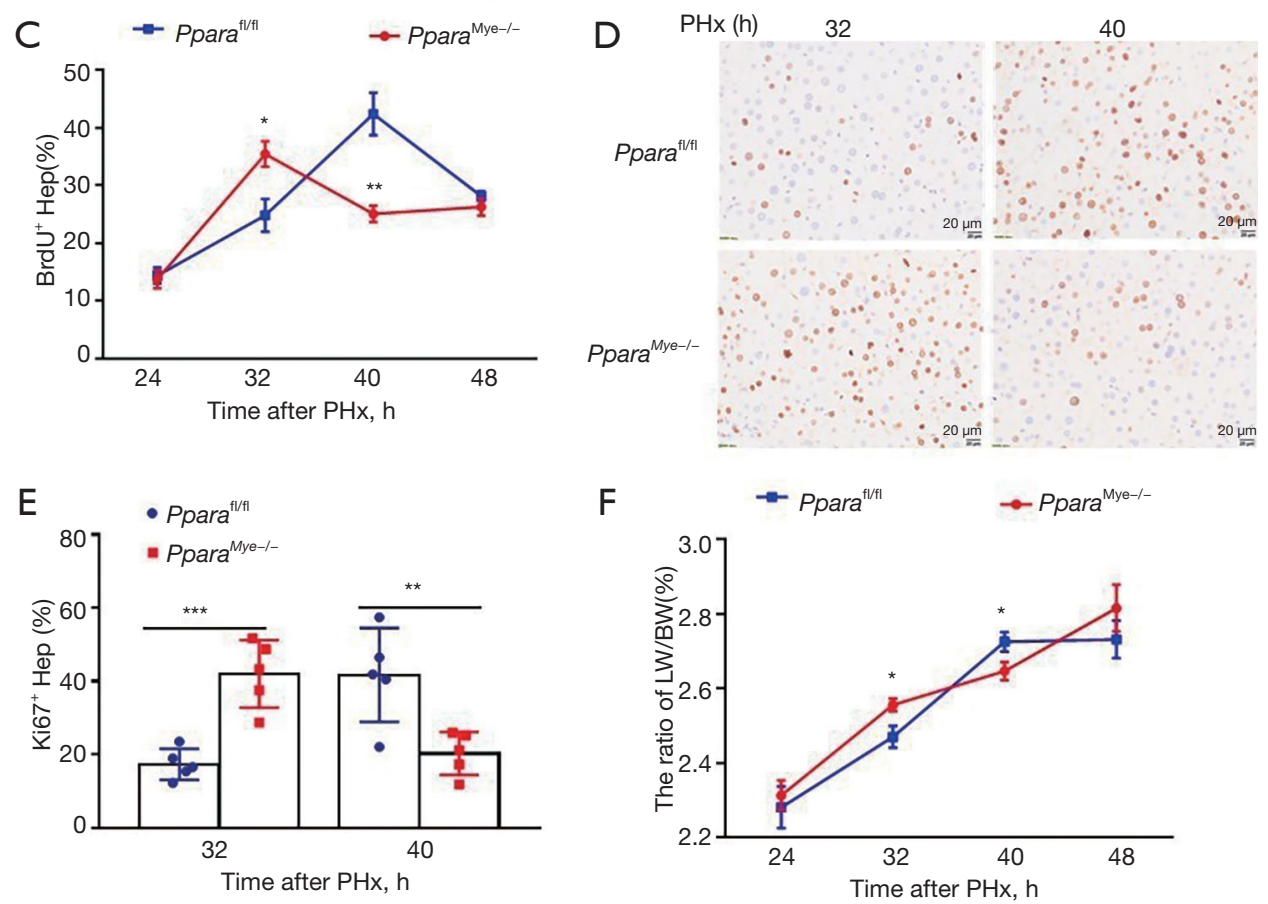

$\mathrm{F}$

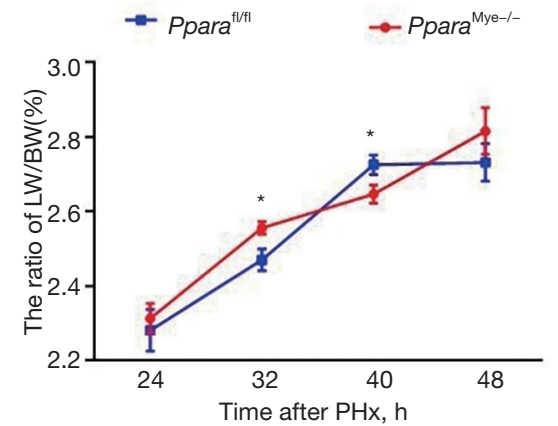

Figure 2 Myeloid PPAR $\alpha$ deficiency mice show accelerated liver regeneration after PHx. (A) Representative H\&E staining for Ppara ${ }^{\mathrm{A} / \mathrm{Al}}$ and Ppara $^{\text {Mye-/- }}$ livers at 24, 32, 40, and $48 \mathrm{~h}$ after PHx. The arrows refer to mitotic hepatocytes. (B) Representative IHC staining for BrdU in Ppara $^{\mathrm{A} / \mathrm{Al}}$ and Ppara $^{\text {Mye-/- }}$ livers at 24, 32, 40, and $48 \mathrm{~h}$ after PHx. (C) BrdU ${ }^{+}$hepatocyte/total hepatocyte ratios at indicated time points. (D) Representative IHC staining for Ki67 in Ppara $^{\mathrm{A} / \mathrm{fl}}$ and $\mathrm{Ppara}^{\text {Mye-/- }}$ livers at 32 and $40 \mathrm{~h}$ after PHx. (E) Ki67 hepatocyte/total hepatocyte ratios at indicated time points. (F) The ratio of $\mathrm{LW} / \mathrm{BW}$ at indicated time points. Data are expressed as means $\pm \mathrm{SD}, \mathrm{n}=5-11 .{ }^{*}, \mathrm{P}<0.05 ;{ }^{* *}, \mathrm{P}<0.01$; ***, $\mathrm{P}<0.001$. PHx, partial hepatectomy; LW/BW, liver weight/body weight. 
A

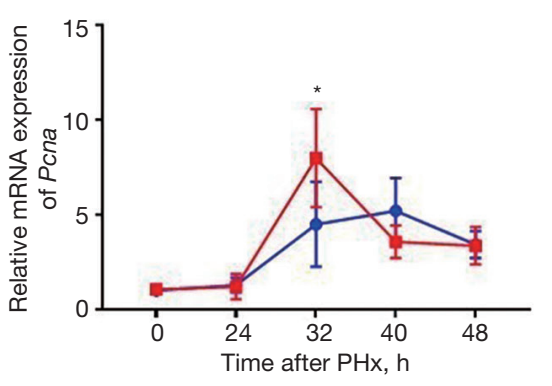

C

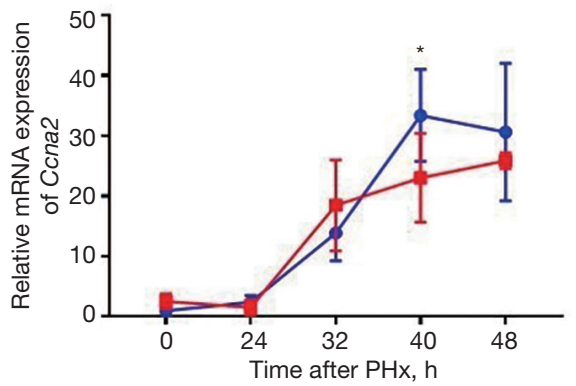

B

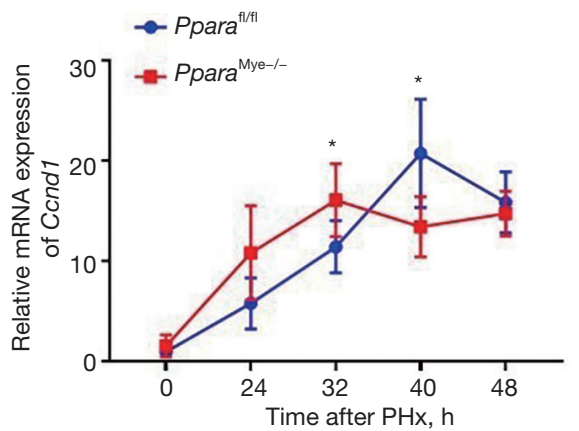

$\mathrm{D}$

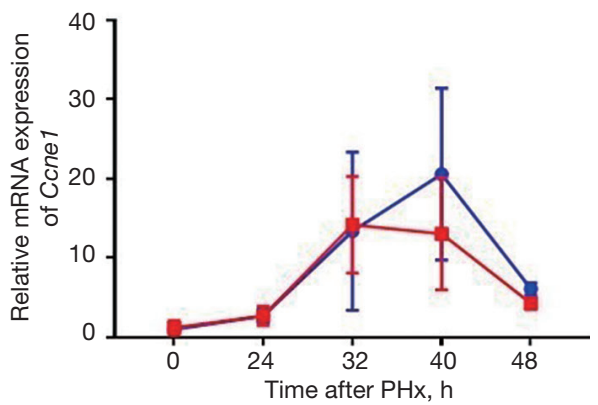

$\mathrm{E}$
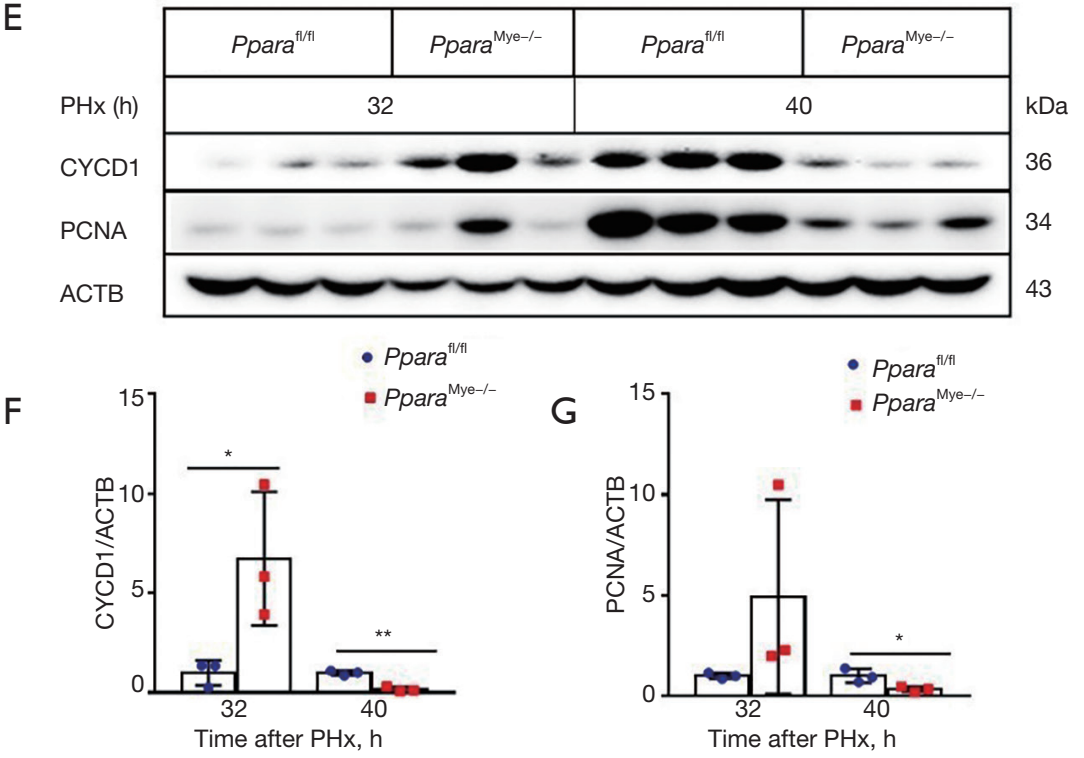

Figure 3 Myeloid PPAR $\alpha$ deficiency mice show increased cell cycle-related gene expression at $32 \mathrm{~h}$ after PHx. (A-D) qPCR analysis for mRNA levels of cell cycle related gene Pcna, Ccnd1, Ccna2, and Ccne1 in Ppara ${ }^{\mathrm{Al/t}}$ and $P$ para ${ }^{\mathrm{Mye}-/-}$ liver at 0, 24, 32, 40, and $48 \mathrm{~h}$ after PHx (n=5). (E-G) Western blot analysis of CYCD1 and PCNA protein levels in Ppara ${ }^{\mathrm{A} / \mathrm{f}}$ and Ppara ${ }^{\text {Mye-/ }}$ liver at 32 and $40 \mathrm{~h}$ after PHx (n=3). Data are expressed as means $\pm \mathrm{SD}$. *, $\mathrm{P}<0.05 ;{ }^{* *}, \mathrm{P}<0.01$. PHx, partial hepatectomy; qPCR, quantitative real-time RT-PCR.

mice (Figure $5 A, 5 B$ ). In vitro, the liver macrophages were isolated to measuring macrophage polarization related gene expression. The results showed increased M1 macrophage marker Il6, Tnfa expression and decreased M2 macrophage marker, Arg1, expression in liver macrophages at $32 \mathrm{~h}$ after PHx (Figure 5C). To further explore the role of myeloid PPAR $\alpha$ in macrophage polarization, the BMDMs were treated with vehicle or LPS for $3 \mathrm{~h}$, as PHx leads to 


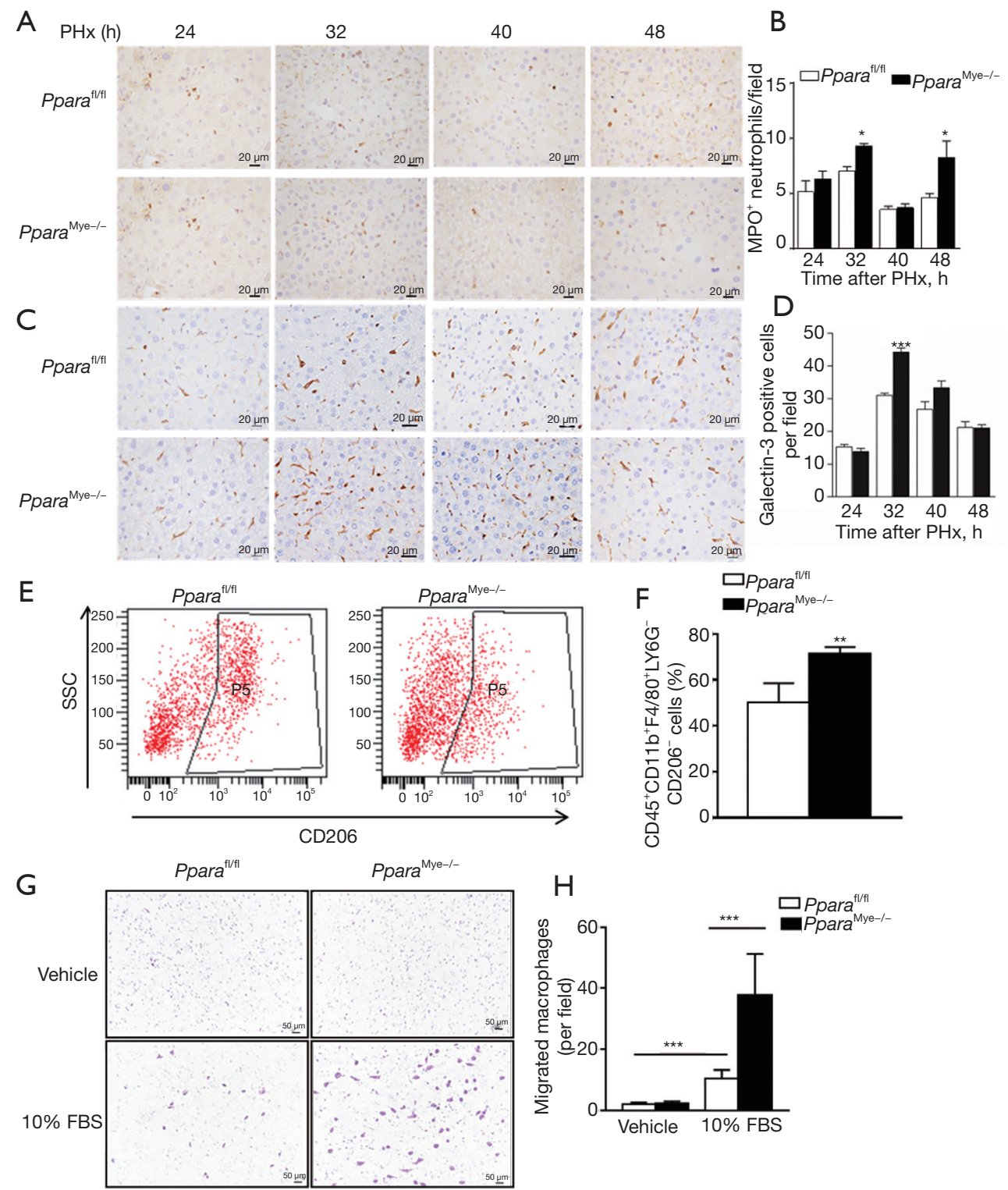

Figure 4 Myeloid PPAR $\alpha$ deficiency promotes M1 phenotype macrophages infiltration to the liver at $32 \mathrm{~h}$ after PHx. (A,B) Representative IHC staining for MPO in Ppara $^{\mathrm{f} / \mathrm{l} /}$ and $\mathrm{Ppara}^{\mathrm{Mye}-/-}$ livers at 24, 32, 40, and $48 \mathrm{~h}$ after PHx (A) and quantification of MPO ${ }^{+}$cells (B) (n=5). (C,D) Representative IHC staining for galectin-3 in Ppara ${ }^{\mathrm{f} / \mathrm{f}}$ and $P$ para ${ }^{\mathrm{Mye}-/-}$ livers at 24, 32, 40, and $48 \mathrm{~h}$ after PHx (C) and quantification of galectin- $3^{+}$cells (D) (n=5). (E,F) Flow cytometry analysis of $\mathrm{CD}^{+} 5^{+} \mathrm{CD} 11 \mathrm{~b}^{+} \mathrm{F} 4 / 80^{+} \mathrm{LY}_{6 \mathrm{G}}^{-} \mathrm{CD} 206^{-}$cell subtype in the $P_{p a r a}{ }^{\mathrm{A} / \mathrm{fl}}$ and $P$ para ${ }^{\mathrm{Mye}-/-}$ livers at $32 \mathrm{~h}$ after PHx and quantification $(\mathrm{n}=4) .(\mathrm{G}, \mathrm{H})$ Representative images of macrophage migration upon vehicle or $10 \%$ FBS stimulation by transwell assay $(\mathrm{G})$ and quantification $(\mathrm{H})(\mathrm{n}=6)$. Data are expressed as means $\pm \mathrm{SD}$. ${ }^{*}, \mathrm{P}<0.05 ;{ }^{* *}, \mathrm{P}<0.01 ;{ }^{* * *}, \mathrm{P}<0.001$. $\mathrm{PHx}$, partial hepatectomy; MPO, myeloperoxidase; SSC, side scatter.

elevation of serum levels of LPS, qPCR analysis showed increased M1 macrophage marker Il6, Tnfa expression and decreased M2 macrophage marker, $\operatorname{Arg} 1$, expression in BMDMs of Ppara ${ }^{\mathrm{Mye}-/}$ mice (Figure $5 D-5 F$ ). However, no difference was found in $C d 206$ expression of BMDMs from $P_{p a r a}{ }^{\mathrm{f} / \mathrm{fl}}$ and $\mathrm{Ppara}^{\mathrm{Mye}-/-}$ mice after LPS stimulation (Figure 5G). In all, these results indicate that myeloid PPAR $\alpha$ promotes macrophage polarization into proinflammatory $\mathrm{M} 1$ phenotype, thus accelerates the process of liver regeneration. 

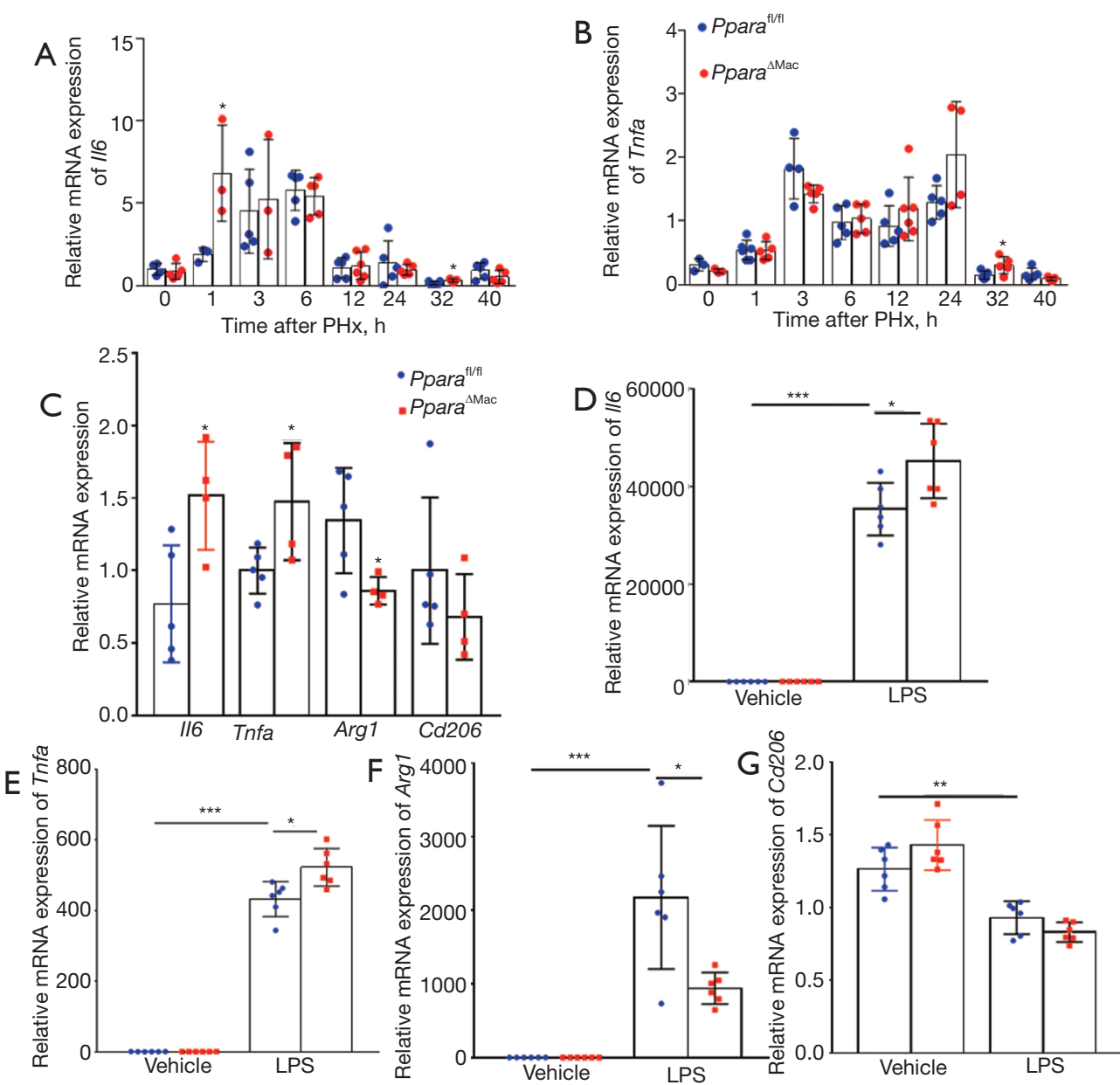

Figure 5 Myeloid PPAR $\alpha$ deficiency enhances BMDMs polarization to M1 phenotype. (A,B) qPCR analysis of Il6 and Tnfa mRNA expression in livers of $\mathrm{Ppara}^{\mathrm{A} / \mathrm{f}}$ and $\mathrm{Ppara}{ }^{\mathrm{Mye}-\mathrm{-}}$ mice at indicated time points (n=3-6). (C) qPCR analysis of Il6, Tnfa, Arg1 and Cd206 mRNA levels in liver macrophages of $\mathrm{Ppara}^{\mathrm{A} / \mathrm{fl}}$ and $\mathrm{Ppara}^{\mathrm{Mye-}-\mathrm{-}}$ mice at $32 \mathrm{~h}$ after PHx (n=4-5). (D-G) qPCR analysis of Il6, Tnfa, Arg1 and Cd206 mRNA levels in BMDMs of $P_{p a r a}{ }^{\mathrm{f} / \mathrm{fl}}$ and $\mathrm{Ppara}^{\mathrm{Mye}-\mathrm{-}}$ mice treated with vehicle or LPS $(100 \mathrm{ng} / \mathrm{mL})$ for $3 \mathrm{~h}(\mathrm{n}=6)$. Data are expressed as means \pm SD. *, $\mathrm{P}<0.05$; **, $\mathrm{P}<0.01$; **, $\mathrm{P}<0.001$. BMDMs, bone marrow-derived macrophages; $\mathrm{PHx}$, partial hepatectomy; LPS, lipopolysaccharide.

\section{Myeloid PPARa deficiency increases STAT3 phosphorylation in liver at 32 b after $\mathrm{PH}$}

It is widely known that STAT3, a key transcript factor, mediating the effect of IL-6 on hepatocyte survival and proliferation after $\mathrm{PHx}$ (6), while STAT1 activation plays a role in inhibiting liver regeneration $(31,32)$. To exploring the molecular mechanism for the accelerated liver regeneration in Ppara $^{\text {Mye-/- }}$ mice, STAT3 and STAT1 phosphorylation was assessed by Western blot. An increase of phosphorylated STAT3 in Ppara ${ }^{\text {Mye-/- }}$ mice was observed at $32 \mathrm{~h}$ after PHx, although phosphorylation of STAT3 was decreased at $40 \mathrm{~h}$ after PHx (Figure 6A,6B), which was consistent with accelerated hepatocyte proliferation.
However, no difference of phosphorylation of STAT1 expression was found between $P_{p a r a}{ }^{\mathrm{fl} / \mathrm{fl}}$ and $\mathrm{Ppara}^{\mathrm{Mye}-/}$ liver at 32 or $40 \mathrm{~h}$ after $\mathrm{PHx}$ (Figure 6A,6C). These results suggesting that myeloid PPAR $\alpha$ may delay liver regeneration via IL-6/STAT3 signaling.

\section{Discussion}

In the current study, myeloid disruption of PPAR $\alpha$ led to accelerated liver regeneration after PHx. In addition, myeloid PPAR $\alpha$ deficiency markedly increased intrahepatic neutrophils and macrophages, especially M1 macrophages infiltration, as well as the expression of inflammatory 


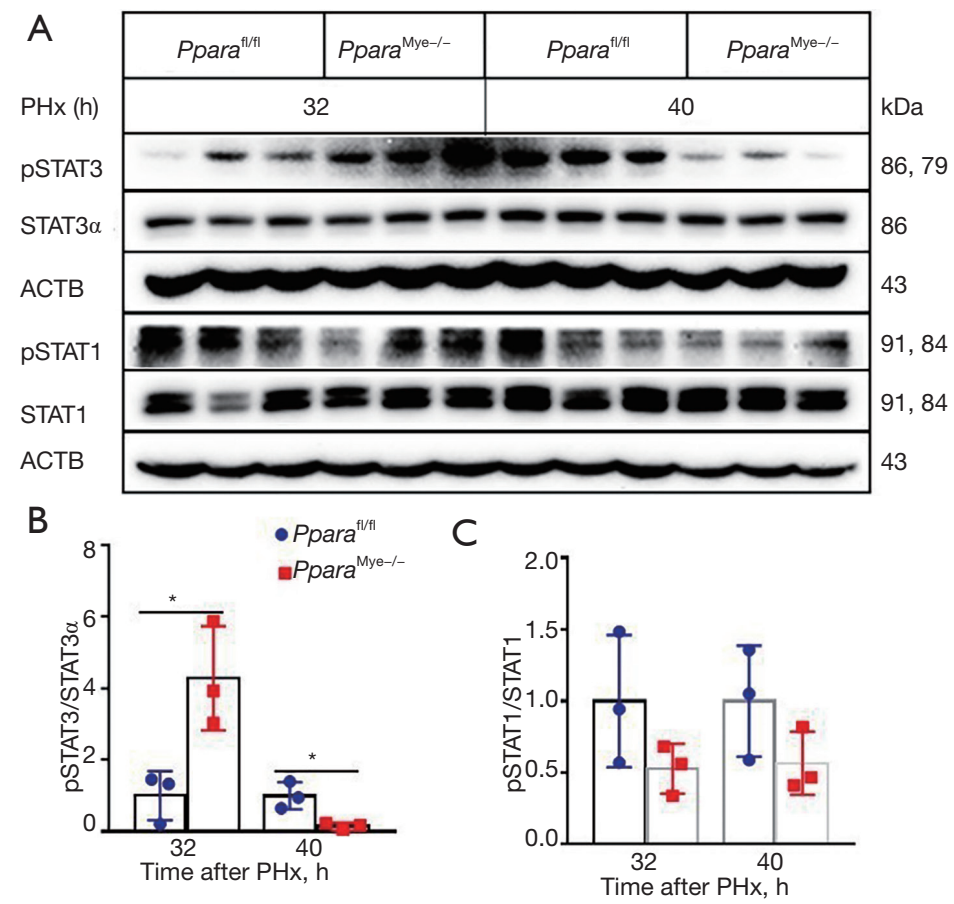

Figure 6 Myeloid PPAR $\alpha$ deficiency increases STAT3 phosphorylation in liver at $32 \mathrm{~h}$ after partial hepatectomy (PHx). (A) Western blot analysis of phosphorylated and total protein of STAT3, and STAT1 in Ppara ${ }^{\mathrm{A} / \mathrm{f}}$ and Ppara ${ }^{\text {Mye-/- }}$ livers at 32 and $40 \mathrm{~h}$ after PHx. (B,C) Quantification of phosphorylated STAT3 (B) and STAT1 (C). Data are expressed as means \pm SD, $n=3 .{ }^{*}, \mathrm{P}<0.05$.

factors, such as IL-6 and TNF- $\alpha$, which are essential for efficient liver regeneration $(33,34)$. As a result, STAT3, a central component in the inflammatory signaling cascade mediating the mitogenic responses of hepatocytes to inflammatory factors after $\mathrm{PHx}(6,35)$, was significantly activated. Accordingly, enhanced cyclin D1 induction in regenerating livers of $\mathrm{Ppara}^{\mathrm{Mye}-/-}$ mice was observed. These results demonstrate that liver regeneration is modulated by intrahepatic immune microenvironment but not hepatic parenchymal cells alone.

PPAR $\alpha$ is a ligand-inducible nuclear receptor of clinical interest as fibrate drug target via controlling fatty acid metabolism in various metabolic disorders (36). Short-term PPAR $\alpha$ agonist treatment was shown to induce hepatocyte proliferation and hepatomegaly in rodents $(15,37,38)$, which is mainly hepatocyte PPAR $\alpha$ dependent, as either wholebody or hepatocyte-specific PPAR $\alpha$ knockout completely abolished this hepatic proliferation $(18,20)$. Sustained PPAR $\alpha$ activation contributed to hepatocarcinoma in rodents $(13,14,39)$. It was proposed that the underlying mechanism is PPAR $\alpha$-dependent downregulation of microRNA Let7c, which in turn released the repression of oncogene c-Myc $(40,41)$. All the above findings emphasized a critical role of PPAR $\alpha$ in peroxisome proliferator-induced hepatocyte proliferation. In the context of PHx, whole-body PPAR $\alpha$-deficient mice exhibited a significant impairment of liver regeneration, which was associated with altered expression of genes involved in cell cycle control, cytokine signaling, and fat metabolism (16). However, compared to whole-body PPAR $\alpha$-knockout mice, hepatocyte-specific PPAR $\alpha$-deficient mice showed a less extent of delay in $\mathrm{PHx}$-induced liver regeneration by inhibiting cell cycle progression and lipid metabolism, indicating an intrinsic compensative or restrictive mechanism for PPAR $\alpha$ from other cell types. In this study, a significant increase of hepatocyte proliferation as well as cell cycle gene Ccnd1 mRNA and protein levels was observed in Ppara ${ }^{\text {Mye-/- }}$ mice at $32 \mathrm{~h}$ post $\mathrm{PHx}$, which suggests that myeloid PPAR $\alpha$ deficiency accelerates $\mathrm{PHx}$-induced liver regeneration, thus indicating that myeloid PPAR $\alpha$ might serve as an endogenous restrictive mechanism for the proliferative effects of hepatocyte PPAR $\alpha$ activation.

Emerging evidence support the crucial role of myeloid cells in PHx-induced liver regeneration (4,42-44). Myeloid cells secret proinflammatory cytokines, such as IL-6 and TNF- $\alpha$, which are known to activate quiescent hepatocytes 
enter cell cycle (29). In this study, myeloid PPAR $\alpha$ deficiency significantly increased the infiltration of macrophages and neutrophils into the livers, especially M1 macrophages, which is consistent with the anti-inflammatory properties of PPAR $\alpha$ in macrophages and other cell types, such as endothelial cells $(11,45)$. In addition, chemotaxis mediators, such as osteopontin, monocyte chemoattractant protein 1 (MCP-1), and intercellular adhesion molecule-1 (ICAM-1) recruit macrophages to liver tissues after PHx (10,46-48), myeloid PPAR $\alpha$ deficiency significantly enhanced the migratory compacity at $32 \mathrm{~h}$ after $\mathrm{PHx}$, which may account for increased macrophage infiltration to liver tissues. Although further studies are still needed for the precise mechanism for how PPAR $\alpha$ activation yields an antiinflammatory profile, a possible hypothesis is that PPAR $\alpha$ negatively inferences with proinflammatory transcription factors, such as NF- $\mathrm{KB}$ and AP1 (11).

Genetic manipulation or pharmacological inhibitors illustrate that IL-6/STAT3 pathway is necessary for the initiation of hepatocyte mitogenesis and proliferation (23), while STAT1 activation plays a role in inhibiting liver regeneration $(31,32)$. As a downstream of IL-6, STAT3 also play an anti-inflammatory role in macrophage (49). On the contrary, STAT1 serve as a pro-inflammatory transcription factors in macrophage (49). In this study, myeloid PPAR $\alpha$ deficiency enhanced the phosphorylation of STAT3 in liver at $32 \mathrm{~h}$ after PHx, but have no influence on the phosphorylation of STAT1. Although STAT3 serve as a marker of M2 macrophage, hepatocytes IL-6/ STAT3 pathway activation is very important for efficient liver regeneration after $\mathrm{PHx}$. These results confirmed the key role of IL-6/STAT3 pathway in accelerated liver regeneration in myeloid Ppara-deficient mice.

In conclusion, this study indicates that myeloid PPAR $\alpha$ restricts $\mathrm{PHx}$-induced liver regeneration via inhibiting IL-6/STAT3 pathway, thus providing a potential target for manipulating liver regeneration under the conditions of liver injury or liver transplantation.

\section{Acknowledgments}

Funding: This work was supported by National Natural Science Foundation of China (81370521, 81670400 , and 91739120), National Key R\&D Program of China (2017YFC0211600), Support Project of High-level Teachers in Beijing Municipal Universities in the Period of 13th Five-year Plan (CIT\&TCD20190332), The Key Science and Technology Project of Beijing Municipal Institutions
(KZ202010025032).

\section{Footnote}

Reporting Checklist: The authors have completed the ARRIVE reporting checklist. Available at https://hbsn. amegroups.com/article/view/10.21037/hbsn-20-688/rc

Data Sharing Statement: Available at https://hbsn. amegroups.com/article/view/10.21037/hbsn-20-688/dss

Conflicts of Interest: All authors have completed the ICMJE uniform disclosure form (available at https://hbsn. amegroups.com/article/view/10.21037/hbsn-20-688/coif). The authors have no conflicts of interest to declare.

Ethical Statement: The authors are accountable for all aspects of the work in ensuring that questions related to the accuracy or integrity of any part of the work are appropriately investigated and resolved. Experiments were performed under a project license (AEEI-2018-127) granted by ethics board of Capital Medical University, in compliance with Chinese guidelines for the care and use of animals.

Open Access Statement: This is an Open Access article distributed in accordance with the Creative Commons Attribution-NonCommercial-NoDerivs 4.0 International License (CC BY-NC-ND 4.0), which permits the noncommercial replication and distribution of the article with the strict proviso that no changes or edits are made and the original work is properly cited (including links to both the formal publication through the relevant DOI and the license). See: https://creativecommons.org/licenses/by-nc-nd/4.0/.

\section{References}

1. Forbes SJ, Newsome PN. Liver regeneration - mechanisms and models to clinical application. Nat Rev Gastroenterol Hepatol 2016;13:473-85.

2. Fausto N, Campbell JS, Riehle KJ. Liver regeneration. Hepatology 2006;43:S45-53.

3. Duncan AW, Dorrell C, Grompe M. Stem cells and liver regeneration. Gastroenterology 2009;137:466-81.

4. Michalopoulos GK. Hepatostat: Liver regeneration and normal liver tissue maintenance. Hepatology 2017;65:1384-92.

5. Michalopoulos GK, Bhushan B. Liver regeneration: 
biological and pathological mechanisms and implications. Nat Rev Gastroenterol Hepatol 2021;18:40-55.

6. Taub R. Liver regeneration: from myth to mechanism. Nat Rev Mol Cell Biol 2004;5:836-47.

7. Li N, Hua J. Immune cells in liver regeneration. Oncotarget 2017;8:3628-39.

8. Yin S, Wang H, Bertola A, et al. Activation of invariant natural killer $\mathrm{T}$ cells impedes liver regeneration by way of both IFN-gamma- and IL-4-dependent mechanisms. Hepatology 2014;60:1356-66.

9. Weston CJ, Zimmermann HW, Adams DH. The Role of Myeloid-Derived Cells in the Progression of Liver Disease. Front Immunol 2019;10:893.

10. Selzner N, Selzner M, Odermatt B, et al. ICAM-1 triggers liver regeneration through leukocyte recruitment and Kupffer cell-dependent release of TNF-alpha/IL-6 in mice. Gastroenterology 2003;124:692-700.

11. Bougarne N, Weyers B, Desmet SJ, et al. Molecular Actions of PPARalpha in Lipid Metabolism and Inflammation. Endocr Rev 2018;39:760-802.

12. Woods CG, Burns AM, Bradford BU, et al. WY-14,643 induced cell proliferation and oxidative stress in mouse liver are independent of NADPH oxidase. Toxicol Sci 2007;98:366-74.

13. Hays T, Rusyn I, Burns AM, et al. Role of peroxisome proliferator-activated receptor-alpha (PPARalpha) in bezafibrate-induced hepatocarcinogenesis and cholestasis. Carcinogenesis 2005;26:219-27.

14. Klaunig JE, Babich MA, Baetcke KP, et al. PPARalpha agonist-induced rodent tumors: modes of action and human relevance. Crit Rev Toxicol 2003;33:655-780.

15. Wang C, Youssef J, Cunningham M, et al. Correlation between thyroid hormone status and hepatic hyperplasia and hypertrophy caused by the peroxisome proliferatoractivated receptor alpha agonist $\mathrm{Wy}-14,643$. J Carcinog 2004;3:9.

16. Anderson SP, Yoon L, Richard EB, et al. Delayed liver regeneration in peroxisome proliferator-activated receptoralpha-null mice. Hepatology 2002;36:544-54.

17. Wheeler MD, Smutney OM, Check JF, et al. Impaired Ras membrane association and activation in PPARalpha knockout mice after partial hepatectomy. Am J Physiol Gastrointest Liver Physiol 2003;284:G302-12.

18. Xie G, Yin S, Zhang Z, et al. Hepatocyte Peroxisome Proliferator-Activated Receptor alpha Enhances Liver Regeneration after Partial Hepatectomy in Mice. Am J Pathol 2019;189:272-82.

19. Chinetti G, Fruchart JC, Staels B. Peroxisome proliferator- activated receptors (PPARs): nuclear receptors at the crossroads between lipid metabolism and inflammation. Inflamm Res 2000;49:497-505.

20. Brocker CN, Yue J, Kim D, et al. Hepatocyte-specific PPARA expression exclusively promotes agonist-induced cell proliferation without influence from nonparenchymal cells. Am J Physiol Gastrointest Liver Physiol 2017;312:G283-99.

21. Wang H, Feng D, Park O, et al. Invariant NKT cell activation induces neutrophil accumulation and hepatitis: opposite regulation by IL-4 and IFN-gamma. Hepatology 2013;58:1474-85.

22. Mitchell C, Willenbring H. Addendum: A reproducible and well-tolerated method for $2 / 3$ partial hepatectomy in mice. Nat Protoc 2014. doi: 10.1038/nprot.2014.122.

23. Wang H, Park O, Lafdil F, et al. Interplay of hepatic and myeloid signal transducer and activator of transcription 3 in facilitating liver regeneration via tempering innate immunity. Hepatology 2010;51:1354-62.

24. Aparicio-Vergara M, Tencerova M, Morgantini C, et al. Isolation of Kupffer Cells and Hepatocytes from a Single Mouse Liver. Methods Mol Biol 2017;1639:161-71.

25. Qu A, Shah YM, Manna SK, et al. Disruption of endothelial peroxisome proliferator-activated receptor gamma accelerates diet-induced atherogenesis in LDL receptor-null mice. Arterioscler Thromb Vasc Biol 2012;32:65-73.

26. Kang LI, Mars WM, Michalopoulos GK. Signals and cells involved in regulating liver regeneration. Cells 2012;1:1261-92.

27. Su AI, Guidotti LG, Pezacki JP, et al. Gene expression during the priming phase of liver regeneration after partial hepatectomy in mice. Proc Natl Acad Sci U S A 2002;99:11181-6.

28. White P, Brestelli JE, Kaestner KH, et al. Identification of transcriptional networks during liver regeneration. J Biol Chem 2005;280:3715-22.

29. Fausto N. Liver regeneration. J Hepatol 2000;32:19-31.

30. Atri C, Guerfali FZ, Laouini D. Role of Human Macrophage Polarization in Inflammation during Infectious Diseases. Int J Mol Sci 2018;19:1801.

31. Sun R, Park O, Horiguchi N, et al. STAT1 contributes to dsRNA inhibition of liver regeneration after partial hepatectomy in mice. Hepatology 2006;44:955-66.

32. Gao B, Wang H, Lafdil F, et al. STAT proteins - key regulators of anti-viral responses, inflammation, and tumorigenesis in the liver. J Hepatol 2012;57:430-41.

33. Streetz KL, Luedde T, Manns MP, et al. Interleukin 6 and 
liver regeneration. Gut 2000;47:309-12.

34. Fazel Modares N, Polz R, Haghighi F, et al. IL-6 Transsignaling Controls Liver Regeneration After Partial Hepatectomy. Hepatology 2019;70:2075-91.

35. Li W, Liang X, Kellendonk C, et al. STAT3 contributes to the mitogenic response of hepatocytes during liver regeneration. J Biol Chem 2002;277:28411-7.

36. Blaschke F, Takata Y, Caglayan E, et al. Obesity, peroxisome proliferator-activated receptor, and atherosclerosis in type 2 diabetes. Arterioscler Thromb Vasc Biol 2006;26:28-40.

37. Elcombe CR, Elcombe BM, Foster JR, et al. Hepatocellular hypertrophy and cell proliferation in Sprague-Dawley rats following dietary exposure to ammonium perfluorooctanoate occurs through increased activation of the xenosensor nuclear receptors PPARalpha and CAR/PXR. Arch Toxicol 2010;84:787-98.

38. Youssef J, Badr M. Enhanced hepatocarcinogenicity due to agonists of peroxisome proliferator-activated receptors in senescent rats: role of peroxisome proliferation, cell proliferation, and apoptosis. ScientificWorldJournal 2002;2:1491-500.

39. Peters JM, Cheung C, Gonzalez FJ. Peroxisome proliferator-activated receptor-alpha and liver cancer: where do we stand? J Mol Med (Berl) 2005;83:774-85.

40. Shah YM, Morimura K, Yang Q, et al. Peroxisome proliferator-activated receptor alpha regulates a microRNAmediated signaling cascade responsible for hepatocellular proliferation. Mol Cell Biol 2007;27:4238-47.

41. Qu A, Jiang C, Cai Y, et al. Role of Myc in hepatocellular proliferation and hepatocarcinogenesis. J Hepatol 2014;60:331-8.

Cite this article as: Xie G, Song Y, Li N, Zhang Z, Wang X, Liu Y, Jiao S, Wei M, Yu B, Wang Y, Wang H, Qu A. Myeloid peroxisome proliferator-activated receptor $\alpha$ deficiency accelerates liver regeneration via IL-6/STAT3 pathway after $2 / 3$ partial hepatectomy in mice. HepatoBiliary Surg Nutr 2022;11(2):199-211. doi: 10.21037/hbsn-20-688
42. Nachmany I, Bogoch Y, Sivan A, et al. CD11b(+) Ly6G(+) myeloid-derived suppressor cells promote liver regeneration in a murine model of major hepatectomy. FASEB J 2019;33:5967-78.

43. Izumi T, Imai J, Yamamoto J, et al. Vagus-macrophagehepatocyte link promotes post-injury liver regeneration and whole-body survival through hepatic FoxM1 activation. Nat Commun 2018;9:5300.

44. Nishiyama K, Nakashima H, Ikarashi M, et al. Mouse CD11b+Kupffer Cells Recruited from Bone Marrow Accelerate Liver Regeneration after Partial Hepatectomy. PLoS One 2015;10:e0136774.

45. Massimi I, Pulcinelli FM, Piscitelli VP, et al. Non-steroidal anti-inflammatory drugs increase MRP4 expression in an endometriotic epithelial cell line in a PPARa dependent manner. Eur Rev Med Pharmacol Sci 2018;22:8487-96.

46. Wen Y, Feng D, Wu H, et al. Defective Initiation of Liver Regeneration in Osteopontin-Deficient Mice after Partial Hepatectomy due to Insufficient Activation of IL-6/Stat3 Pathway. Int J Biol Sci 2015;11:1236-47.

47. Czaja MJ, Geerts A, Xu J, et al. Monocyte chemoattractant protein 1 (MCP-1) expression occurs in toxic rat liver injury and human liver disease. J Leukoc Biol 1994;55:120-6.

48. Marra F, DeFranco R, Grappone C, et al. Increased expression of monocyte chemotactic protein-1 during active hepatic fibrogenesis: correlation with monocyte infiltration. Am J Pathol 1998;152:423-30.

49. Marino S, Cilfone NA, Mattila JT, et al. Macrophage polarization drives granuloma outcome during Mycobacterium tuberculosis infection. Infect Immun 2015;83:324-38. 
Supplementary

Table S1 Primers for qPCR

\begin{tabular}{|c|c|}
\hline Gene & Primer sequence $\left(5^{\prime}-3^{\prime}\right)$ \\
\hline \multirow[t]{2}{*}{ Ppara } & F: CTGCCTTCCCTGTGAACTGA \\
\hline & R: ACAGAGCGCTAAGCTGTGAT \\
\hline \multirow[t]{2}{*}{ Ccna2 } & F: TCGCTGCATCAGGAAGACC \\
\hline & R: CTTAAGAGGAGCAACCCGTCG \\
\hline \multirow[t]{2}{*}{ Cond1 } & F: TCAAGTGTGACCCGGACTGC \\
\hline & R: CCTTGGGGTCGACGTTCTG \\
\hline \multirow[t]{2}{*}{ Cone1 } & F: ACTTCCCGTCTTGAATTGGGG \\
\hline & R: AGGATGACGCTGCAGAAAGT \\
\hline \multirow[t]{2}{*}{ Pcna } & F: TCGTCTCACGTCTCCTTGGT \\
\hline & R: TTTTGGACATGCTGGTGAGGT \\
\hline \multirow[t]{2}{*}{ Tnfa } & F: CCACCACGCTCTTCTGTCTAC \\
\hline & R: AGGGTCTGGGCCATAGAACT \\
\hline \multirow[t]{2}{*}{116} & F: TGATGCACTTGCAGAAAACA \\
\hline & R: ACCAGAGGAAATTTTCAATAGGC \\
\hline \multirow[t]{2}{*}{$\operatorname{Arg} 1$} & F: GTAGACCCTGGGGAACACTAT \\
\hline & R: ATCACCTTGCCAATCCCCAG \\
\hline \multirow[t]{2}{*}{ Cd206 } & F: TTCAGCTATTGGACGCGAGG \\
\hline & R: GAATCTGACACCCAGCGGAA \\
\hline
\end{tabular}

